\title{
Identification of the Holothurian species of the Red Sea and Gulf of Aqaba using DNA barcoding technique.
}

\author{
Mohammed I. Ahmed ${ }^{1}$; Maher. A. Aamer' ${ }^{1}$ and Andrew J. Lawrence ${ }^{2}$ \\ 1- Suez Canal University, Egypt \\ 2- The University of Chester, UK
}

\begin{abstract}
Holothurians are one of the most dominant taxa in marine communities in the Red Sea and Gulf of Aqaba. However, despite their wide distribution their taxonomic diversity is poorly understood. Recent studies have shown that many species thought to have broad distributions are actually a complex of allied species, with long standing questions regarding the identification of certain sea cucumber species. A total of 140 specimens of sea cucumber tissues were collected for DNA examination. A total of 18 sea cucumber species were identified along the Egyptian coast of the Red Sea and Gulf of Aqaba; Holothuria spinefra; Holothuria sp.; Holothuria leucospilota; Holothuria impatiens; Holothuria nobilis; Holothuria fuscogilva; Holothuria scabra; Holothuria atra; Actinopyga mauritiana; Actinopyga sp. Nov; Actinopyga crassa; pearthonthuria graeefei; Bohadchia tenussima; Bohadchia marmorata; Bohadchia cousteaui; stichopus sp. and Synaptula sp. These species were distinguished using morphological techniques. The DNA sequences of COI gene produced 17 different distinctive clades of sea cucumber. The use of DNA barcoding of the mitochondrial COI gene proves to be a good technique in resolving long standing problems in the identification of sea cucumber.
\end{abstract}

Keywords: Holothurians species, Red Sea, Gulf of Aqaba, DNA barcoding.

\section{INTRODUCTION}

The identification of all genera and species of Holothuroids depends almost entirely on the morphological characters of the animals and the form and combinations of the calcareous spicules found in the body wall and podia (Pearson, 1914; Deichmann, 1958; Rowe, 1969; and Clark and Rowe, 1971). Other anatomical characters such as the number and arrangement of the tentacles, the presence or absence of the anal teeth or papillae, polian vesicles, stone canal and cuvierian organs are variable to some extent, even within species and therefore can rarely be used satisfactorily in classification (Clark and Rowe, 1971).

The current method of sea cucumber identification needs a great deal of expertise and proves to be unable to solve some long standing question on the sea cucumber taxonomy. Despite the fact that holothurians classification has a long and rich history, basic the current method for identification of sea cucumber was not able to solve the identification of some of the very common still problematic species such as Pearsonothuria graeffei (Levin et al., 1984), also known as Holothuria graeefi (Semper, 1868) and Bohadschia graeffei (Panning, 1929). The juvenile and adult are so different, that they could be mistaken for species belonging to different genera (Massin, 1996). Finally Pearsonothuria graeffei were placed on a separate genus (Levin, et al., 1984; Conand 1998; Massin 1999; Samyn 2000; Lane et al. 2000; Marshal et al. 2001) in order to resolve their taxonomic uncertainty. Holothuria nobilis and Holothuria fuscogilva are two of the $1^{\text {st }}$ class commercial sea cucumber 
species. They are common along the tropical and subtropical Indo-Pacific Ocean and Red Sea. However, there is a great argument about the taxonomy and identification of the two species. Cherbonnier, 1980, distinguished the two forms and considered them as two different species. Rowe and Gates, 1995 after examination of extant type specimens, regard $H$. fuscogilva as a junior synonym of $H$. nobilis because of the similarity of both the ecology and ossicles of both species. Massin, 1999 and Samyn, 2003 agreed with them on the fact that they should be considered as synonym. A solid evidence is still needed to resolve such a conflict whether they are the same species or two different species.

The DNA sequence analysis of a uniform target gene to enable species identification has been referred to as DNA barcoding, (Hebert et al., 2003). A short DNA sequence should contain enough information to distinguish between species. The cytochrome c oxidase subunit 1 (CO1) gene has been used as a barcoding gene. One of the advantages of using the COI gene is that the universal primers for this gene are very robust (Folmer et al., 1994; Zhang and Hewitt, 1997).

The main aim of this research is to identify different species of sea cucumber collected from the Northern coast of the Red Sea and Gulf of Aqaba using DNA barcoding technique, and to examine whether the technique was able to resolve long standing taxonomic questions regarding the classification of some Holothurian species.

\section{MATERIALS AND METHODS}

A total of 140 specimens of sea cucumber tentacles tissues were collected for DNA examination. Specimens representing 18 different species from different habitats and localities along the Red Sea coast of Egypt and Gulf of Aqaba. Samples were collected by SCUBA diving from deep water (50m maximum depth) and by snorkeling and hand collection from shallow reef flat areas. Samples for DNA preparations had small parts of the tentacles cut off before releasing the animals. Tissues of sea cucumber were immediately frozen in liquid nitrogen in the field and later transferred to a $-80^{\circ} \mathrm{C}$ freezer.

DNA was extracted from one tentacle tissue sample per specimen using Qiagen DNA easy Tissue Kit \#69504 (Qiagen, Inc., London, UK) following the manufacturer's protocol. A region of the mitochondrial cytochrome oxidase $I$ (COI) gene was amplified using primers $C O 1-278 F 5$ ' CTA ATG ATA GG(AT) GCC CC (CT) GAC ATG GC $3^{\prime}$ and COI-790R 5 ' CCT AGG TAC CC(AG) AA(AT) GG (CT) TCT TGC TT 3' . Polymerase chain reaction was performed which comprised a $94^{\circ} \mathrm{C} / 4$ min initial denaturing step followed by 30 cycles of $94^{\circ} \mathrm{C} / 1 \mathrm{~min}, 55^{\circ} \mathrm{C} / 1 \mathrm{~min}$, and $72^{\circ} \mathrm{C} / 1 \mathrm{~min}$. A final elongation step of $72 \mathrm{C} / 10 \mathrm{~min}$ was used. The hot lid method was used. Products were then visualized on a $1.5 \%$ agarose gel stained with ethidium bromide. Both strands were sequenced from remaining PCR products.

Multiple COI sequences were manually entered and aligned using the codoncode aligner Editor Program. Sequence assembly and verification was performed with the aid of Aligner VX (CodonCode inc, NewYork). The sequences were aligned using clustal automated alignment algorithm (Thompson et al., 1994) then checked manually on the Mesquite software where codon positions were assigned. ML trees were constructed using RAXML (Stamatakis et al., 2008). Confidence in nodes was assessed using the bootstrap with 1000 pseudo-replicates performed in RAXML. Trees were uploaded into IToL (letunic and Bork, 2006). 


\section{RESULTS}

DNA was extracted from 140 different individuals of sea cucumber collected from different locations and habitats along the Red Sea coast and Gulf of Aqaba. Only 120 PCR products were obtained and then sequenced for the COI gene. PCR products of 650bp were obtained from all samples (Figure-1). A total of 18 sea cucumber species were identified along the Egyptian coast of the Red Sea and Gulf of Aqaba using morphological characters and spicules examination; Holothuria spinefra; Holothuria sp; Holothuria leucospilota; Holothuria impatiens; Holothuria nobilis; Holothuria fuscogilva; Holothuria scabra; Holothuria atra; Actinopyga mauritiana; Actinopyga sp. Nov; Actinopyga crassa; pearthonthuria graeefei; Bohadchia tenussima; Bohadchia marmorata; Bohadchia cousteaui; stichopus sp and Synaptula $\mathrm{sp}$.

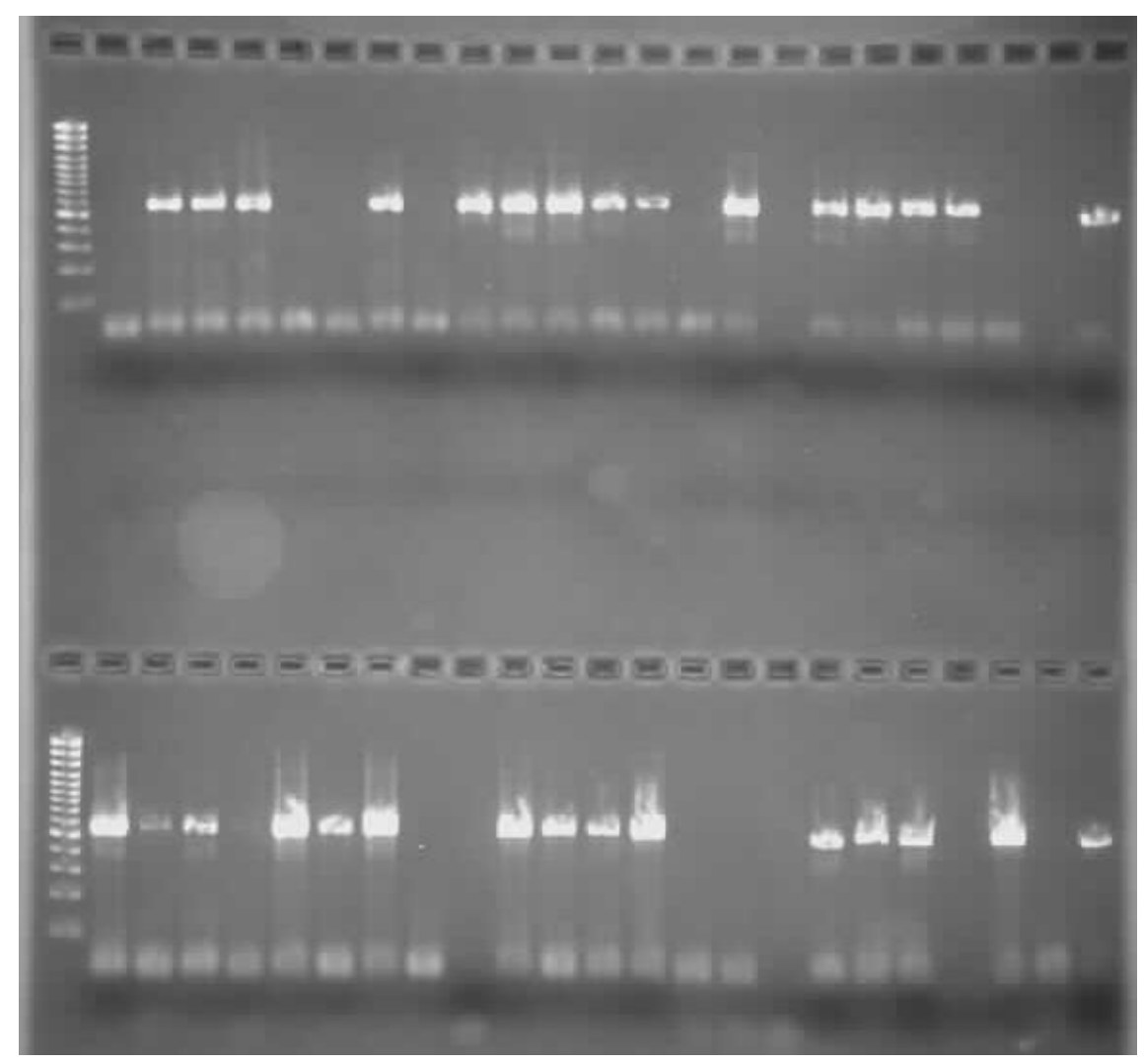

Fig. 1: PCR final products visualized on Agarose gel stained with Ethidium bromide.

All sequences were submitted to genbank and accession numbers were obtained for all samples. Sequence analysis of the COI gene for the sea cucumber samples collected from the Red Sea showed 13 distinct clades of sea cucumber species. Figure 2 showed that all the Bohadchia species collected from the Red Sea and Gulf of Aqaba formed one clade with no genetic differences between them; those (species) are morphologically different; P. graeefei formed a distinct clade from both the Holothurians and Bohadchians with boots strap value of $100 \%$. The same figure also showed the significant divergence between the two morphs of A. mauritiana collected from the Red Sea coast of. Holothuria spinefra and Holothuris sp. were clustered together with no divergence between them; Holothuria nobilis and Holothuria fuscogilva formed two separate clades. 


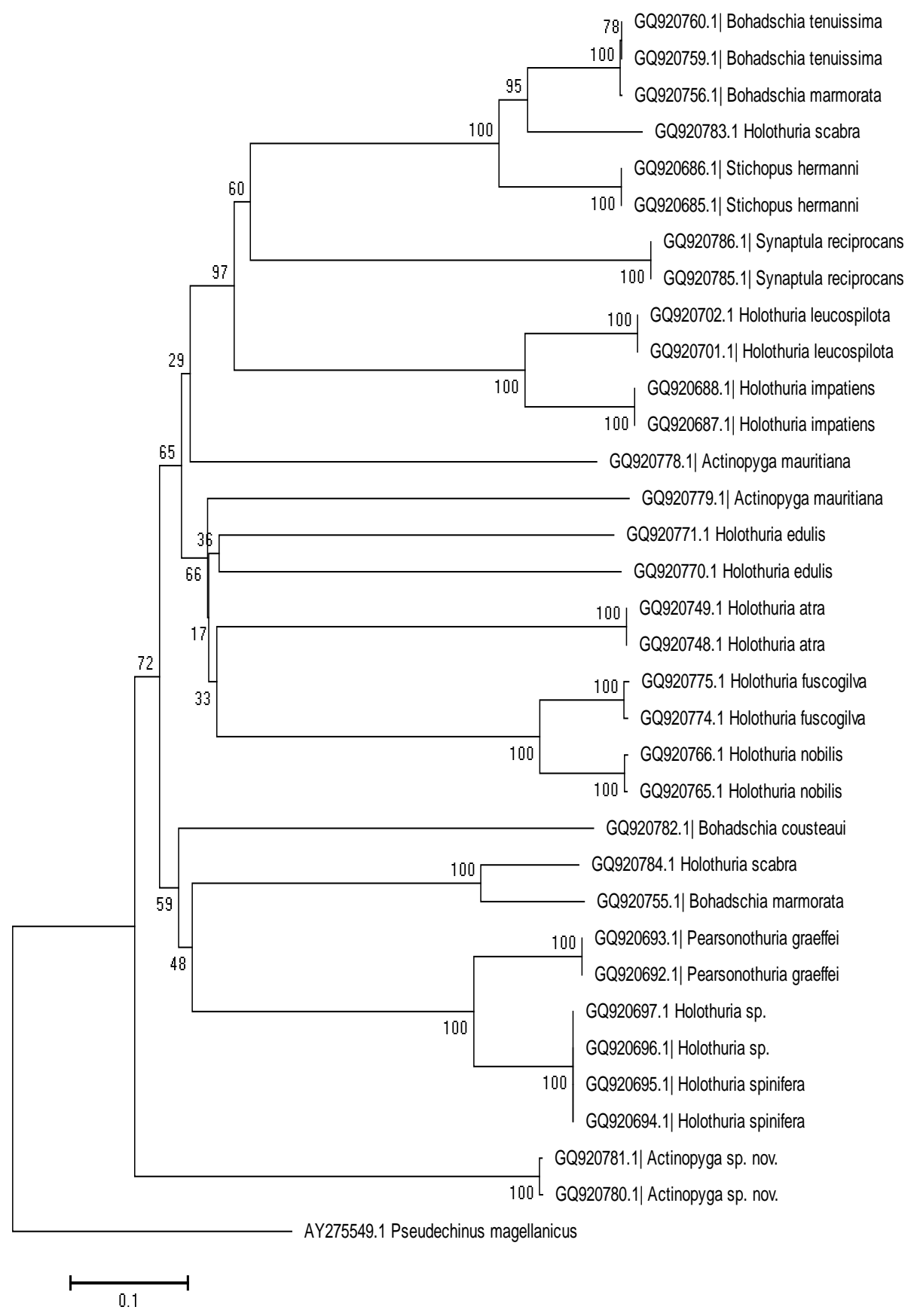

Fig. 2: Neighbour joining tree of all sea cucumber species collected from the Egyptian Red Sea coast constructed using MEGA.6 Pseudechinus magellanicus used as outgroup. All data with genbank accession number.

\section{DISCUSSION}

The morphological examination of all the specimens collected from the Red Sea coast of Egypt resulted on the identification of 18 different species of sea cucumber. All the species were identified using morphological characteristics and spicules examinations and by using the collection at the British Museum of Natural History $(\mathrm{BMNH})$ and the available keys for sea cucumber identification (Clark and Rowe, 1971). PCR products were recovered from all sea cucumber species collected from the Red Sea and there was no evidence of the nuclear pseudogenes that have complicated 
some studies employing degenerate COI primers (Williams and Knowlton 2001). The COI sequences of sea cucumber possessed a high level of diversity and most analysed sea cucumbers were placed in the correct order or phylum.

The use of DNA barcoding of the mitochondrial COI gene proved to be a good technique in resolving long standing problems in the identification of sea cucumber; with the gene found to harbor enough diversity not only between species but also within species. Thirteen distinct clades of sea cucumber species were found after the construction of phylogeny tree. From our results it was clear in the Bohadchia clade that Bohadchia tenussima, and Bohadchia marmorata were clustered together with no genetic differences, these species are morphologically different with different colour patterns (Samyan, 2003). That might suggest that they should be merged together as morph type of the same species rather than separate species. More data is required about the ecology, behaviour and distribution of the Bohadchians species along the Red Sea coast of Egypt and Gulf of Aqaba in order to confirm the result.

On the other hand two morphs of the Actinopyga mauritiana species complex were collected from the Red Sea. The molecular examination of the two morphs showed that they are genetically different and should be considered as different species. The same case with $H$. nobilis and $H$. fuscogilva our molecular examination supported the theory that they should be separated as different species (as suggested by Cherbonnier, 1980). But we disagree with Rowe and Gates, 1995 and Massin, 1999. who regard $H$. fuscogilva as a junior synonym of $H$. nobilis.

The molecular examination of the COI gene of Pearsonothguria graeffei (Levin et al., 1984), also called Holothuria graeefi (Semper, 1868) and Bohadschia graeffei (Panning, 1929) should be considered as separate genus from Holothurians and Bohadchian. The results also showed that Holothuria sp. collected and identified as different species from $H$. spinefra is genetically identical to the identified species. Examination of the $C O I$ gene of 18 identified seacucumber species resulted in the discrimination of thirteen different clades representing possibly thirteen different species of sea cucumber, more research would be required in the taxonomy of different marine animals using the DNA barcoding technique.

\section{ACKNOWLEDGMENT}

This research was funded by the STDF (Science and technology Development Fund). Through the fisheries and aquaculture call; Project no 5686. We would like to thank STDF officials for their support during different phases of the project.

\section{REFERENCES}

Cherbonnier G. (1980). Holothuries de Nouvelle-Calédonie. Bulletin du Muséum national d'Histoire naturelle de Paris, Quatrième série 2, section A (3): 615667.

Clark AM. and Rowe FWE. (1971). Monograph of Shallow-water Indo-West Pacific Echinoderms. London, Trustees of the British Museum (Natural History), i-vii, 1-238, pls 1-31.

Conand, C. (1981). Sexual cycles of three commercially important holothurian species (Echinodermata) from the lagoons of New Caledonia. Bull Mar Sci., 31: 523-544 
Conand, C. (1998). Holothurians. In: Carpenter, K. \& Niels, V. (eds.) FAO species identification guide. The marine living resources of the Western Central Pacific. vol. 2 cephalopods, crustaceans, holothurians and sharks, 1157-1190.

Deichmann E. (1958). The Holothurioidea collected by the Velero III and IV during the years 1932 to 1954, part II. Aspidochirotida. Allan Hancock Pacific Expedition 11: 239-349, pls 1-9.

Folmer, O.; Black, M.; Hoeh, W.; Lutz, R. and Vrijenhoek, R. (1994). DNA primers for amplification of mitochondrial cytochrome c oxidase subunit I from diverse metazoan invertebrates. Mol. Mar. Biol. Biotechnol., 3: 294-299.

Hebert PDN.; Cywinska A.; Ball SL.; and deWaard JR. (2003). Biological identifications through DNA barcodes. Proc R Soc Lond B., 270: 313-321

Lane, D.J.W.; Marsh, L.M.; Vanden Spiegel and Rowe, F.W.E. (2000). Echinoderm fauna of the South China Sea: an inventory and analysis of distribution pattern. The raffles Bulletin of Zoology Supplement, 8: 459-493.

Lawrence A.J.; Ahmed M.; Hanafy M.; Gabr H.; Ibrahim A. and Gab-Alla A. (2004). Status of the sea cucumber fishery in the Red Sea - The Egyptian experience. In: Lovatelli A., Conand C., Purcell S., Uthicke S., Hamel J.-F. and Mercier A. (eds). Advances in sea cucumber aquaculture and management. FAO Fisheries Technical Paper. No. 463. Rome, FAO. 2004. 457 p.

Letunic and Bork (2006). Bioinformatics, 23(1):127-8

Levin, V.S.; Kalinin, V.I. and Stonik, V. A. (1984). "Chemical characters and taxonomic revision of holothurian Bohadschia graeffei (Semper) as refer to erection of a new genus" Biol Morya 1984: 33-38 Comment: (in Russian with English summary)

Marshall N.; Milledge SAH. and Afonso PS. (2001). Stormy Seas for Marine Invertebrates - Trade in Sea Cucumbers, Seashells and Lobsters in Kenya, Tanzania and Mozambique. TRAFFIC East Southern Africa, Kenya, 70 pp.

Massin, C. (1996). Results of the Rumphius Biohistorical Expedition to Ambon (1990). Part 4. The Holothuroidea (Echinodermata) collected at Ambon during the Rumphius Biohistorical Expedition. Zoologische Verhandelingen 307: 1-53.

Massin, C. (1999). Reef-dwelling Holothuroidea (Echinodermata) of the Spermonde Archipelago (South-West Sulawesi, Indonesia). Zoologische Verhandelingen 329: 1 -144.

Panning, A. (1929). Die Gattung Holothuria. Mitteilungen aus dem Hamburgischen Zoologischen Museum und Institut, Hamburg, 44: 91-138.

Pearson J. (1914). Proposed re-classification of the genera Mülleria and Holothuria. Spolia Zeylanica, 9: 163-172, 1

Rowe FEW. (1969). A review of the family Holothuriidae (Holothurioidea: Aspidochirotida). Bulletin of the British Museum (Natural History) Zoology, 18: 119-170.

Rowe FEW. and Gates, J. (1995). Echinodermata, in A. Wells (ed.), Zoological Catalogue of Australia, vol. 33. (Melbourne: CSIRO Australia), pp. 510.

Samyn Y. (2000). Conservation of aspidochirotid holothurians in the littoral waters of Kenya. SPC Bêche-de mer Information Bulletin 13: 12-17.

Samyn, Y. (2003). Shallow-water Holothuroidea (Echinodermata) from Kenya and Pemba Island (Tanzania). Studies in Afrotropical Zoology 292:1-158.

Semper C. (1868). Holothurien. Reisen im Archipel der Philippinen. Holothurien. 2. Wissenschaftliche Resultate. Weisbaden : i-x, 1-288, pls 1-40. Leipzig.

Stamatakis, A.; Hoover, p. and Rougemont, J. (2008). A Rapid Bootstrap Algorithem for the RAxML web-server, Systematic Biology, 75(5): 758-771 
Thompson, J. D.; D. G. Higgins and T. J. Gibson. (1994). ClustalW: improving the sensitivity of progressive multiple sequence alignment through sequence weighting, position-specific gap penalties, and weight matrix choice. Nucleic Acids Res., 22: 4673-4680.

Williams, S. T. and Knowlton, N. (2001). Mitochondrial pseudogenes are pervasive and often insidious in the snapping shrimp Alpheus. Mol. Biol. Evol., 18: 1484-1493.

Zhang, D.-X. and Hewitt, G. M. (1997). Assessment of the universality and utility of a set of conserved mitochondrial primers in insects. Insect Mol. Biol., 6:143-150.

\section{ARABIC SUMMARY}

$$
\begin{aligned}
& \text { تعريف انواع خيار البحر Holothurians من البحر الأحمر وخليج العقبة باستخدام تقنية الحمض النووي }
\end{aligned}
$$

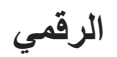

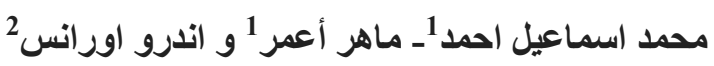

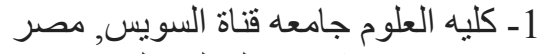

$$
\begin{aligned}
& \text { 2- جامعه شستر بالمملكه المتحده }
\end{aligned}
$$

تعتبر مجمو عه خيار البحر Holothurians واحدة من الأنواع الأكثر هيمنة في المجتمعات البحرية في التهي

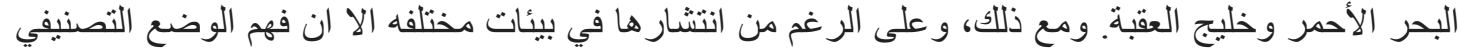

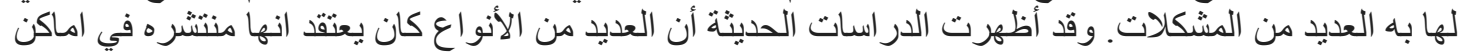

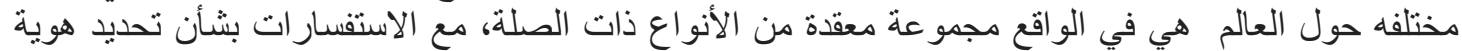

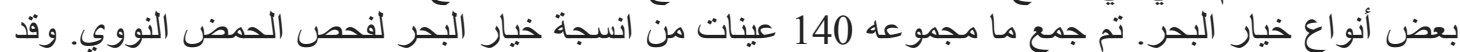

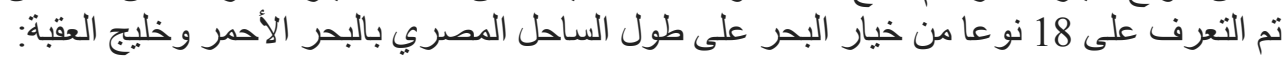
Holothuria spinefra; Holothuria sp.; Holothuria leucospilota; Holothuria impatiens; Holothuria nobilis; Holothuria fuscogilva; Holothuria scabra; Holothuria atra; Actinopyga mauritiana; Actinopyga sp. Nov; Actinopyga crassa; pearthonthuria graeefei; Bohadchia tenussima; Bohadchia marmorata; Bohadchia cousteaui; stichopus sp. and Synaptula sp.

وقد اثتتت تقنيه الحمض النووي الرقمي وفصل جين الستوكروم اوكسيديس 1 قدرتها علي الفصل بين انواع خيار

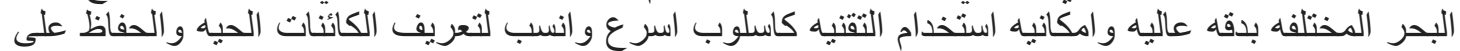

